\title{
ERA V. KUZNETSOVA: A LIFE IN SCHOLARSHIP AND SCHOLARSHIP AS LIFE*
}

\author{
Liudmila Babenko \\ Yuri Kazarin \\ Ural Federal University, \\ Yekaterinburg, Russia
}

The authors consider the life and scholarly activity of Era Vasilyevna Kuznetsova (1927-1988), a doctor of philology, professor, and the first head of the Department of the Modern Russian Language at Ural State University. The article describes her rich inner world of emotions and scholarly thinking, focusing on the peculiarities of her academic style and the manner and direction of her work. Her biography is considered within the historical and social context and the circumstances of her private life, scholarly research, and achievements. Being an outstanding linguist, Kuznetsova was a remarkable and open-minded person with a wonderful capacity for communication. She sincerely believed in social justice and was convinced that it was possible to change the world ethically and socially in accordance with the laws of social harmony. She was a talented scholar: one could not doubt her linguistic gift. Her manner of thinking was logical; she easily became fascinated with new ideas and knew how to introduce them to others. She was a prominent scholar and the leader of a research group which laid the foundations for lexicological and lexicographic studies at Ural State University. Kuznetsova released her main works during the 1970s and 1980s, when structural semantic linguistics was being formed amidst heated discussions and arguments. In academia, she is known as the most influential specialist in lexical semantics, the systemic organisation of vocabulary, and the semantics and grammar of the Russian verb, the author and editor of a number of monographs and a textbook, and the organiser and head of the Russian Verb research group, which gave rise to the Ural Semantic School in the late 1990s.

Keywords: E.V. Kuznetsova; lexicology; lexicography; the Russian Verb research group; Ural State University; Ural Semantic School.

\footnotetext{
* The work is sponsored by a grant of the Russian Science Foundation (poject № 16-18-02005).

** The first publication of E. V. Kuznetsova's biography: [Казарин]. See also: [Русская глагольная лексика: пересекаемость парадигм: Памяти Эры Васильевны Кузнецовой; Уральская семантическая школа, 2011; Уральская семантическая школа, 2013; Человек системный].

${ }^{* * *}$ Citation: Babenko, L., Kazarin, Yu. (2018). Era V. Kuznetsova: A Life in Scholarship and Scholarship as Life. In Quaestio Rossica, Vol. 6, № 3, p. 877-888. DOI 10.15826/qr.2018.3.333.

Цитирование: Babenko L., Kazarin Yu. Era V. Kuznetsova: A Life in Scholarship and Scholarship as Life // Quaestio Rossica. Vol. 6. 2018. № 3. P. 877-888. DOI 10.15826/ qr.2018.3.333.
}

(C) Babenko L., Kazarin Y., 2018 Quaestio Rossica • Vol. 6 • 2018 • № 3, p. 877-888 
Рассмотрены личность и научная деятельность Эры Васильевны Кузнецовой (1927-1988), доктора филологических наук, профессора, первого заведующего кафедрой современного русского языка Уральского государственного университета им. А. М. Горького. Обращено внимание на раскрытие ее богатого внутреннего мира, мира эмоций и интеллекта, выявление особенностей научного стиля, специфики и манеры научной деятельности. Ее биография рассматривается в историко-социальном контексте и обстоятельствах личной судьбы, научных исканиях и достижениях. Э. В. Кузнецова, будучи выдающимся лингвистом, была неординарным человеком, обладала широким кругозором и удивительной способностью к общению. Она искренне верила в возможность социальной справедливости и этико-социального переустройства мира по законам социальной гармонии. Ее натуре был присущ талант ученого-мыслителя: несомненная лингвистическая одаренность, строгая логика мышления, умение заражаться научными идеями и приобщать к ним других. В ней совмещались качества крупного ученого, высокопрофессионального преподавателя, лидера научного коллектива, заложившего основы и открывшего перспективы для лексикологических и лексикографических исследований в Уральском университете. Основные научные труды Э. В. Кузнецовой были созданы ею в 1970-1980-е гг, когда в острых дискуссиях и спорах формировалось структурно-семантическое направление в лингвистике. В научных кругах она известна как крупный специалист в области лексической семантики, системной организации лексики, семантики и грамматики русского глагола, автор и научный редактор ряда монографий, учебника, организатор и руководитель проблемной группы «Русский глагол», на основе которой к концу 1990-х гг. сформировалась Уральская семантическая школа.

Ключевые слова: Э. В. Кузнецова; лексикология; лексикография; проблемная группа «Русский глагол»; Уральский государственный университет; Уральская семантическая школа.

Era Vasilyevna Kuznetsova was born on 7 February 1927 in the town of Polevskoy, Sverdlovsk Region, to the large family of Maria Konstantinovna and Vasily Nikolayevich Kalugin, an officer of the Red Army, veteran of World War I, and recipient of the Order of St George. Commander of a cavalry regiment and devoted to the ideas of the Revolution during the Civil War, he was awarded the Order of the Red Banner and silver weapons.

To the present day, Polevskoy has remained a town typical of the second half of the $20^{\text {th }}$ century, a synthesis of town and village which developed around a large factory. However, it is also a special place for the Urals, as it is the birthplace of the Russian writer Pavel Bazhov, the glorifier of mining masters famous for his poetic depiction and personification of things as small as stones. This is an important factor for understanding Era Vasilyevna's cultural evolution. It was her father who named her Era, which stands for era $(\mathrm{E})$, revolution $(\mathrm{R})$, and apogee $(\mathrm{A})$. Despite the fact that her father died at the hands of Soviet power, Era Vasilyevna was 
a member of the Party, strongly believing that the Soviets had the ability to build a new society and that the Soviet Union was a country of justice and humanity. However, she was not blinded by her belief in the Soviet future; shortly before her passing, she bitterly recognised that all revolutions ended in blood being shed and that any attempt to change the social structure of the world is accompanied by 'crimes'. This was not the disillusionment of a hardened communist but the revelation of a person capable of critical thinking, comparison, and reaching conclusions.

While Kuznetsova was talented and goal-oriented by nature, she was not a favourite of fortune. She faced difficulties both in her family life and career. She dreamt of studying philosophy and went to Moscow State University to do so, but as she was a daughter of a political prisoner, she was not allowed to enter the Faculty of Philosophy. Instead, she was permitted to enter the Faculty of Philology, where she studied from 1944 to 1949. Among her teachers were outstanding philologists, such as V. V. Vinogradov, S. I. Ozhegov, R. A. Avanesov, etc. She was a devoted student completely absorbed by her work. Being an emotional and lively person, she took part in the social life of both the faculty and university. There were remarkable people among her fellow students, too: E. A. Zemskaya, G. A. Zolotova, and S. P. Lopushanskaya later became eminent linguists. She defended her graduate thesis cum laude, her academic supervisor being S. I. Ozhegov, an outstanding lexicographer and scholar. Hence, it is no surprise that her academic life came to be closely connected with issues of semantics, lexicology, and lexicography.

Upon graduating with honours, it was recommended that she continue her studies as a postgraduate student. However, the university refused to enrol her, since she was a daughter of an 'enemy of the people. She had to look for justice and assert her rights to carry out research: this defined her spirit, as she frequently had to rely on herself in challenging circumstances and demonstrate strength of mind. This was a typical situation at the time. Professor G. A. Zolotova, Era Kuznetsova’s fellow student at university, writes:

We were peers with Era. I remember her well: she was a slim girl with a face of a Madonna, thin, graceful, and natural. Everyone seemed to like her, she was very emotional, too, and all her feelings could be seen on her face. She was sincere, open, passionate, and susceptible. She never used to hide her feelings from others, and always shared her happiness. Everyone was aware if she was in love with someone. Just like others, she wore modest and simple clothes, and even looked poor. But no one ever felt uncomfortable or miserable because of the state of things in those times. Many girls only had one dress, but they shared common aspirations and hopes, looking forward to future success and enjoying their studies.

We got close just before graduation. Era, E. A. Zemskaya, and I were proposed for postgraduate studies and very soon afterwards denied enrolment for one and the same reason: the year of 1937. They acted deceitfully and claimed that we all had bad references. But we knew for a fact that the Dean's Office 
had provided good references for us. We tried to clarify things in the Party Committee, where we were told about our untrustworthiness as daughters of political prisoners, about anti-Soviet dissent, etc. They heard us retort, 'Little do you know about the psychology of Soviet youth [Золотова, c. 487-488].

In her memoirs, S. P. Lopushanskaya depicts the student community of Moscow University and relates warmly about Era Kuznetsova (née Kalugina):

MSU, the 1940s, the hard war and postwar years. But it is worth mentioning that there were special people among university professors and students, ones fascinated by research, brought up by intellectual work and their friends' support, by kindness and selflessness. They had an innate idea of honesty and decency. This mutual trust was to be tested by the years to come. The student community was formed in the academic group, in the reading halls of the Gorky Library, and especially in the student hostel on 32 Stromynka Str. The pictures that I still have are rather rare: in one of them, you can see a group of friends, graduates of the Russian Language Faculty of the 1950s, in front of the monument to M. V. Lomonosov. I also have pictures with Andrey Sinyavsky, Liudmila Matyushenko, Elena Zemskaya, Era Kalugina, and others. I met Erochka at the student hostel, we lived next door there and celebrated holidays together, bought books together, had lots of arguments when discussing what our older peers brought from the front, and what the first foreign trainees of the postwar years told us. Years passed, and I lost contact with some people, some went far away, and some were forgotten. But Era Kalugina [Kuznetsova] still holds a special place in my heart. She was called 'a "very" person', as she was very beautiful, very Russian, very smart, hardworking, principled, and very thoughtful. This is how Era Vasilyevna will be remembered by those who knew her, communicated with her, and worked with her. After the passage of many years had taken us to different places and cities, I met with her in Volgograd in 1987. She took part in the State Examination Commission and generously helped our young university to establish an academic school of lexicology and, more particularly, verb semantics. Books by Era Kuznetsova, her smile and radiant blue eyes, her charm and sincerity are still with us [Лопушанская, с. 488-489].

Between 1950 and 1952, Kuznetsova took a postgraduate course and defended her PhD thesis The Word Stock of the Dialect of Polevskoy District, Sverdlovsk Region in the spring of 1952. Her academic supervisor was Petr Savvich Kuznetsov, a specialist in phonetics, morphology, and Russian dialectology. The topic of her thesis and its materials are directly connected with Era Vasilyevna's native land and her hometown, where she first started doing fieldwork, laying the groundwork for the future dialectological expeditions of the Faculty of Philology. Her first articles were based on the thesis and devoted to the peculiarities of the word stock of the Russian vernacular [Кузнецова, 1958], the structure of a dictionary entry in a regional 
dictionary [Кузнецова, 1960], and the description of reflexive verbs in the dialects of the Central Urals [Кузнецова, 1963].

From March to May 1953, she worked as a senior lecturer at the Department of the Russian Language at Khabarovsk Pedagogical Institute: she then moved to Sverdlovsk (Yekaterinburg), working there until 1962 first as a research assistant and then a senior lecturer at the Department of the Russian Language and General Linguistics of Ural University, headed by its founder P. A. Vovchok from 1940 to 1960. In the 1950s, he put forward the idea of creating the Dictionary of Russian Dialects of the Central Urals, authored a preface to the first volume of the dictionary as its editor, and supervised the work of its contributors. Era Kuznetsova (Glazyrina) joined the project and successfully compiled the section entitled Verb Vocabulary [Словарь русских говоров Среднего Урала]. Her interest in verbs and joint lexicographic work determined Kuznetsova's lifelong academic priorities. At the same time, Kuznetsova published papers on issues connected with verbs, verb semantics, and systemic relations among lexical units. In 1962, Era Vasilyevna had to leave for Donetsk due to family reasons: there, she worked as a senior lecturer of the Department of the Russian Language of Donetsk University until 1968. It was in Donetsk where she wrote and published her first methodical instructions and materials for the specialised seminar Systemic Relations in Vocabulary, which were the basis of her longer textbooks [Кузнецова, 1968].

The field of linguistics in the 1970s saw the development of the concept of semantic dictionaries and their introduction to lexicographic practice. Upon her return to Ural University, Era Vasilyevna actively supported and developed the prophetic ideas of Yu. N. Karaulov, V. V. Morkovkin, and D. N. Shmelyov, which were related to the need to study vocabulary as a system and its representation by means of lexicographic parameters. During the period in question, vocabulary was predominantly classified semantically on logical and notional grounds, where linguistic investigation proceeded from a general notion forming semantic groups of words to the identification and description of such groups. Kuznetsova put forward her own linguistic method to reveal the content of lexical semantic sets of various classes, based on an approach opposite to that used in the conventional study of vocabulary, i. e. starting with the analysis of lexical semantics and proceeding to general notions and basic categories represented by different semantic groups of words. She paid special attention to the development of a methodology that would make it possible to carry out a step-bystep identification of the lexical meanings of verbs: this would reveal basic identifiers that could be further used as bases for lexical semantic groups of words. The basic principles and algorithm of her method were described in her report The Method of Step-by-Step Identification in the Description of Lexical Semantic Groups of Words, which was delivered at an inter-university conference on generative grammar in Tartu and published in the proceedings [Кузнецова, 1967]. 
E. Kuznetsova spent a lot of time and effort working on the development of the general theory of the systemic organisation of vocabulary (especially that of the verb), where she studied the nature of lexical sets and the practical application of the theory connected with the identification of the composition of lexical semantic groups of words belonging to different classes. Later, supervised by E. Kuznetsova and referring to methods of stepby-step identification, a group of her students worked on the systematisation of verb vocabulary and its identification as part of lexical semantic groups. These were presented as lists of verbs and included in the dictionary Lexical Semantic Groups of Verbs [Лексико-семантические группы русских глаголов, 1988].

In 1974, Era Vasilyevna defended her habilitation thesis, entitled Russian Verbs of Object Inclusion as a Functional Semantic Class of Words: On the Notion of Lexical Semantic Groups of Words. G. A. Zolotova warmly recalls the event:

Years passed. In 1974, Era Vasilyevna defended her habilitation thesis in the Academy of Sciences, and I was one of her external examiners. I remember the feast at the Praha restaurant, where we were joined by Khaburgayev and Nikita Tolstoy. The atmosphere was very warm and friendly. E. V. Kuznetsova always grasped new ideas, concepts, and trends. She started studying verb semantics, relying on the concept proposed by Yu. D. Apresyan, in 1960 and took part in conferences on structural linguistics. She occupied a well-deserved and important place in academia: she worked honestly and enthusiastically, as she must have done throughout her life. I have not been to Sverdlovsk, but I think her coworkers loved her. The last time we went to a conference in Voronovo, we stayed in the same room. We shared our excitement before making our reports and talked about everything. She spoke about her family with love and care [Золотова, c. 488].

In 1974, Kuznetsova became the founder and head of the Department of the Modern Russian Language at the Faculty of Philology at Ural State University. She employed a few young lecturers who wrote their theses under her supervision and defended them during the 1980s. Era Vasilyevna's first students were the key specialists of the Department and the core of the scholarly group The Russian Verb. Kuznetsova took great pains to instil genuine academic culture in her scholarly group, which meant effective scholarly communication and exchange, consultation ethics, and the peculiar atmosphere of an academic community.

After 1976, Kuznetsova not only worked on semantics and paradigmatics, but also focused on syntactic aspects. She wrote several works devoted to the word as an element (object) of grammatical and lexical semantic research, grammatical classes of words, and their interaction with lexical semantic groups of words. She studied the statuses of words (onomatheme - syntagma); she substantiated two types of paradigm and examined the category of semantic identifiers; and she studied and worked out the theory of functional semantic groups of words with reference to the systemic 
approach. She also worked out her own method of componential analysis of the lexical meaning of a word, focusing on the functional equivalence of words, especially verbs, as part of a lexical semantic group.

She described her ideas in several works on the student dictionary of semantic and lexical grammatical groups of Russian verbs. In 1980, she published a textbook for the specialised course Russian Vocabulary as a System, which is a noteworthy work [Кузнецова, 1980]. On the one hand, it synthesised all aspects of the lexical system of language (lexical paradigmatics, syntagmatics, and contextology), while, on the other, it had a lot of potential for further study, taking scholarly thought towards systemic functional research. In 1982, Kuznetsova published her innovative textbook The Lexicology of the Russian Language [Кузнецова, 1982; Кузнецова, 1989], which was published twice in the Moscow publishing house Vysshaya Shkola (Higher School) and recommended for all universities of Russia, a mark of high recognition. The textbook has not lost its relevance. Together with the focus on traditional sociolinguistic aspects of the structure of language's word stock, it has sections on systemic structural approaches to the study of language, which had never been done previously, and reflected the achievements of the theoretical study of vocabulary in the 1970s and 1980s. Issues of paradigmatic, syntagmatic, and variant relations, as well as functional equivalence, the interaction of polysemy and synonymy, etc., were considered for the first time in a book meant for university students. Time has demonstrated that the textbook is a bible for every linguist studying Russian lexicology and semasiology.

Era Vasilyevna's scholarly bravery was a factor that helped her contribute to controversial issues regarding the semantics of a sentence: this was connected with the search for methods to describe semantic models with reference to the verb and verb semantics (the denotative direction of syntax) [Кузнецова, 1985]. Kuznetsova's approach to polysemy was also original at the time, as she studied it in terms of its correlation with synonymy as a manifestation of variant relations in vocabulary (the variability of the form of words with identical content in cases of synonymy and the variability of content of words with an identical form in cases of polysemy). In this respect, synonymy was considered first and foremost as functional equivalence [Кузнецова, 1978]. She developed this approach (which belongs to epidigmatics) in her articles, reports, and thesis topics of her postgraduate students, as well as in lectures.

In the mid-1980s, Kuznetsova was wholly involved in joint work. It was then that the research group The Russian Verb started functioning under her supervision. Its work resulted in the reference book and dictionary Lexical Semantic Groups of Russian Verbs and a monograph of the same name (both were published posthumously) [Лексико-семантические группы русских глаголов, 1989]. These works were significant for linguists and university lecturers for teaching Russian as a second language, as vocabulary was not listed alphabetically but thematically, e. g. verbs of motion, speaking, behaviour, etc. This classification of verbal word class- 
es reflected how Russian people conceived of processes and events as part of their worldview, which was essential for understanding the national and cultural peculiarities of the Russian verb.

Era Vasilyevna was a lover of life in all senses of the word; as a scholar, she was not a loner who denied herself all the pleasures of life for the sake of her research. She was an excellent cook and enjoyed having people at her place and treating them to what she lovingly prepared. She preferred traditional Ural cuisine, cooking cottage cheese and onion pastry, cabbage, potato, and mushroom pies, and pelmeni (dumplings). She liked nature, too. Together with her second husband Vladimir Leontyevich, she had a plot of land in a collective garden, with high birches and pear and cherry trees instead of the usual vegetable patches. She dreamt of a detached house of her own in the forest, which she talked about a lot during the last year of her life.

Era Vasilyevna Kuznetsova was a truly Russian person, a hard worker, a homemaker, and a leader at work. She loved life deeply, and she loved her family. She enjoyed holidays, and her house was hospitable. She always welcomed guests and took pleasure in inviting them for feasts with pickled vegetables, snacks, larger dishes, and the ever-present pies and pastry. Such meals were always accompanied by talks, jokes, laughter, and songs. She enjoyed singing solo and singing along. Even at events at the Department, everyone always sang her favourite song The Brigantine Sets Sail... Kuznetsova was a perfect leader: she knew everything about everyone and had a deep understanding of all problems; she was very thoughtful (but not overprotective) and took part in the academic and personal lives of her students and colleagues. She was a figure capable of animating ideas, and her vitality (or, more precisely, excessive vitality) and high speed of life helped her succeed in her personal, social, and academic life. Such people cannot be stopped: they die without love for people, for their vocation, and for life in general. Kuznetsova was a very smart, wise, and kind person. But just like all extremely talented people, she was also extremely naïve: she thought that she was surrounded by people just like her, decent, conscientious, sincere, devoted to a common cause, frank, open, intelligent, selfless, and kind. Era Vasilyevna did not tolerate irresponsibility, indecency, and, above all, meanness and betrayal.

In October 1986, Kuznetsova's second term as head of the Department was coming to an end: being on leave in order to write a preface for a reference book and dictionary of lexical semantic groups of Russian verbs, she asked for her re-election date to be put off until December. She worked at home and rarely came to the university. She got up at 5 am every day and started work. She felt creative and inspired. The previous five years had been very prolific: the result of her scholarly activity for the period was impressive, with everyone admiring its scale, as they continue to do so. She had supervised several $\mathrm{PhD}$ candidates, published numerous anthologies, edited and submitted for publication the Dictionary of Lexical Semantic Groups of Russian Verbs and a joint monograph, made 16 reports at inter-university conferences, and much more. Era Vasilyevna was 59, the average age of a professor today. It was an age when her talent, spiritual potential, and creative abilities were in full 
bloom: it was also an age of wisdom. However, she was not to continue her work: she died suddenly and prematurely at the age of 60 on 28 April 1988. Her academic path was difficult, purposeful, bright, and dynamic.

Era Vasilyevna could only live in an atmosphere of love. She shared her love with the surrounding world and the people around her: her family (her children, grandchildren, husband, and sisters), her students and their family members, her coworkers, and the acquaintances she met throughout her life. Her relationship with her husband was particularly touching, and it could not have been otherwise. They treated each other with tenderness and stood by each other. Every evening, they strolled along the streets of the city, spending time together and showing a lot of love for their children and grandchildren. Being energetic and strong, Era Vasilyevna was not only the centre of her family: much of the Department's everyday life was also fueled by her energy. Her scholarly ideas have not lost their relevance, as they continue to develop in the works of her students: this is vital, since the best way of remembering a person is to do so through actions, through work. Most of the work of her PhD students focused on different aspects of verb semantics and verb vocabulary. After their teacher's death, her students continued their research on structural systemic and functional aspects and focused on lexicography as part of The Russian Verb research group: others, meanwhile, started new academic trends. None of them abandoned academia or stopped looking for new ways to study the Russian language.

Kuznetsova's students did their best to preserve and further develop the Department and the research trend she started, as well as to continue the work of the research group. In the 1990s, it became well known far outside Yekaterinburg and Russia due to the fundamental publications of the Department of the Modern Russian Language: these laid the foundations for the Ural Semantic School [Уральская семантическая школа, 2011; Уральская семантическая школа, 2013], which was being formed at the time. Members of the school continued their research on the fundamental issues of semantics and the systemic organisation of verb vocabulary, which resulted in two monographs published in the late 1990s, and turned to look at the semantics of nouns, adjectives, synonyms, sentences, and fictional texts. They continued working on the theoretical and practical issues of lexicography as part of the research topic of the Ural Semantic School known as Ideographic Lexicography: New Types of Dictionaries and their Role in the Preservation of the National Language and National Culture. Over twenty ideographic dictionaries of different types have been published during this 30-year period, including list-type thesauruses and complex explanatory ideographic dictionaries (see, for example: [Большой толковый словарь русских существительных; Большой толковый словарь русских глаголов; Большой толковый словарь синонимов русской речи; Концептосфера русского языка]).

Kuznetsova was a unique personality: a rare combination of a human being and scholar, a woman and a leader, a teacher and a public figure. Her name was widely known in national linguistics. In every university city of Russia, she used to have like-minded friends, adherents, 
amiable opponents, and scholars she knew well both from their work and social contact. Uniting them all was what unites all linguists - the unity of academic life. Academia, her personal life, and the rhythm of daily existence were the three key factors that helped Kuznetsova stand strong. She was a direct and straightforward person, unbiased in her perception of people and everyday events. One could love her or not: there was no in-between. She rarely remained indifferent, worrying about everything from a scholar's achievements in academic life to their personal problems: she always tried to help, and not only by giving advice. She seemed to see through people and know what they felt deep inside. Era Kuznetsova's ideas, image, and strength will be remembered by scholars for years to come, pushing them to go further and attain their goals.

\section{Список литературы}

Большой толковый словарь русских глаголов : Идеографическое описание. Синонимы. Антонимы. Английские эквиваленты / под ред. Л. Г. Бабенко. М. : АСТ-Пресс Книга, 2007. 576 с.

Большой толковый словарь русских существительных : Идеографическое описание. Синонимы. Антонимы / под ред. Л. Г. Бабенко. М. : АСТ-Пресс Книга, 2005. 864 с.

Большой толковый словарь синонимов русской речи : Идеографическое описание. Антонимы. Фразеологизмы / под ред. Л. Г. Бабенко. М. : АСТ-Пресс Книга, 2008. 784 с.

Золотова Г. А. Слова памяти об Эре Васильевне Кузнецовой. Вспоминания коллег об Эре Васильевне Кузнецовой // Русская глагольная лексика: пересекаемость парадигм : Памяти Эры Васильевны Кузнецовой / под общ. ред. Л. Г. Бабенко. Екатеринбург : Изд-во Урал. ун-та, 1997. С. 487-488.

Казарин Ю. В. Полевской - Москва // Русская глагольная лексика: пересекаемость парадигм : Памяти Эры Васильевны Кузнецовой / под общ. ред. Л. Г. Бабенко. Екатеринбург : Изд-во Урал. ун-та, 1997. С. 266-486.

Концептосфера русского языка: ключевые концепты и их репрезентации в языке и речи (на материале лексики, фразеологии и паремиологии) : словарь / под общ. ред. Л. Г. Бабенко. М. : Азбуковник, 2017. 1024 с.

Кузнецова Э. В. Возвратные глаголы в говорах Среднего Урала // Лингвистический сборник. Вып. 1. Свердловск : Изд-во Урал. ун-та, 1963. С. 84-95.

Кузнецова Э. В. Итоги и перспективы семантической классификации русских глаголов // Семантические классы русских глаголов : межвуз. сб. науч. тр. / редкол. Э. В. Кузнецова и др. Свердловск : Изд-во Урал. ун-та, 1982. С. 3-10.

Кузнеиова Э. В. К вопросу о специфике словарного состава русских народных говоров // Уч. зап. Урал. гос. ун-та. Вып. 2. Языкознание. Свердловск : Изд-во Урал. ун-та, 1958. С. 58-72.

Кузнецова Э. В. Лексикология русского языка : учеб. пособие. 2-е изд., испр. и доп. М. : Высш. школа, 1989. 216 с.

Кузнецова Э. В. Лексикология русского языка : учеб. пособие. М. : Высшая школа, 1982. $216 \mathrm{c}$.

Кузнецова Э. В. Метод ступенчатой идентификации в описании лексико-семантических групп слов // Межвузовская конференция по порождающим грамматикам : тез. докл. Тарту : Тартуск. гос. ун-т, 1967. С. 65-67.

Кузнецова Э. В. Методические указания и материалы к спецсеминару «Системные отношения в лексике». Донецк : [Б. и.], 1968. 79 с.

Кузнецова Э. В. О соотношении многозначности и функциональной эквивалентности слов // Научные доклады высшей школы. Филологические науки. 1978. № 2. С. 97-103.

Кузнецова Э. В. О структуре словарной статьи в областном словаре // Уч. зап. Урал. гос. ун-та. Вып. 3. Языкознание. Свердловск : Изд-во Урал. ун-та, 1960. С. 165-179.

Кузнецова Э. В. Русская лексика как система : учеб. пособие. Свердловск : Изд-во Урал. ун-та, 1980. 89 с. 
Кузнецова Э. В. Семантическая модель предложения с предикатами типа «считать» и способы ее реализации // Деривация и история языка : тез. докл. межвуз. науч. конф. Пермь, 17-19 июня 1985 г. / под ред. С. Ю. Адливанкина, Е. С. Кубряковой, И. Ю. Черепанова и др. Пермь : Изд-во Перм. гос. ун-та, 1985.

Лексико-семантические группы русских глаголов / под ред. Э. В. Кузнецовой. Иркутск : Изд-во Иркутск. гос. ун-та, 1989. 180 с.

Лексико-семантические группы русских глаголов : учеб. словарь-справ. / науч. рук. Э. В. Кузнецова. Свердловск : Изд-во Урал. ун-та, 1988. 152 с.

Лопушанская С. П. Слова памяти об Эре Васильевне Кузнецовой. Вспоминания коллег об Эре Васильевне Кузнецовой // Русская глагольная лексика: пересекаемость парадигм : Памяти Эры Васильевны Кузнецовой / под общ. ред. Л. Г. Бабенко. Екатеринбург : Изд-во Урал. ун-та, 1997. С. 488-489.

Словарь русских говоров Среднего Урала : в 7 т. / гл. ред. П. А. Вовчок. Свердловск : Средне-Урал. книж. изд-во, 1964-1999. (Авт.-сост. разд. «Глагольная лексика» Э. В. Глазырина).

Уральская семантическая школа. Уральский федеральный университет // Энциклопедия когнитивной лингвистики: научные школы и направления. Тамбов : ООО «Цифра», 2013. С. 14-28.

Уральская семантическая школа: история, люди, события / авт.-сост. Ю. В. Казарин. Екатеринбург : Изд-во Урал. ун-та, 2011. 348 с.

Человек системный : Эра Васильевна Кузнецова // Изв. Урал. гос. ун-та. Сер. 2. Гуманитарные науки. 2010. № 4 (82). С. 232-235.

\section{References}

Babenko, L. G. (Ed.). (2005). Bol'shoi tolkovyi slovar'russkikh sushchestvitel'nykh. Ideograficheskoe opisanie. Sinonimy. Antonimy [Great Explanatory Dictionary of Russian Nouns. Ideographic Description. Synonyms. Antonyms]. Moscow, AST-Press Kniga. 864 p.

Babenko, L. G. (Ed.). (2007). Bol'shoi tolkovyi slovar' russkikh glagolov. Ideograficheskoe opisanie. Sinonimy. Antonimy. Angliiskie ekvivalenty [Great Explanatory Dictionary of Russian Verbs. Ideographic Description. Synonyms. Antonyms. English Equivalents]. Moscow, AST-Press Kniga. 576 p.

Babenko, L. G. (Ed.). (2008). Bol'shoi tolkovyi slovar'sinonimov russkoi rechi. Ideograficheskoe opisanie. Antonimy. Frazeologizmy [Great Explanatory Dictionary of Synonyms of Russian Speech. Ideographic Description. Antonyms. Phraseologisms]. Moscow, AST-Press Kniga. 784 p.

Babenko, L. G. (Ed.). (2017). Kontseptosfera russkogo yazyka: klyuchevye kontsepty $i$ ikh reprezentatsii v yazyke i rechi (na materiale leksiki, frazeologii i paremiologii). Slovar' [The Conceptosphere of the Russian Language: Key Concepts and their Representations in Language and Speech (Based on Vocabulary, Phraseology, and Paremiology). Dictionary]. Moscow, Azbukovnik. 1024 p.

Chelovek sistemnyi: Era Vasil'evna Kuznetsova [A Systematic Person: Era Vasilyevna Kuznetsova]. (2010). In Izvestiya Ural'skogo gosudarstvennogo universiteta. Seriya 2. Gumanitarnye nauki. No. 4 (82), pp. 232-235.

Kazarin, Yu. V. (1997). Polevskoi - Moskva [Polevskoy - Moscow]. In Babenko, L. G. (Ed.). Russkaya glagol'naya leksika: peresekaemost' paradigm. Pamyati Ery Vasil'evny Kuznetsovoi. Yekaterinburg, Izdatel'stvo Ural'skogo universiteta, pp. 266-486.

Kazarin, Yu. V. (Ed.). (2011). Ural skaya semanticheskaya shkola: istoriya, lyudi, sobytiya [The Ural Semantic School: History, People, Events]. Yekaterinburg, Izdatel'stvo Ural'skogo universiteta. $348 \mathrm{p}$.

Kuznetsova, E. V. (1958). K voprosu o spetsifike slovarnogo sostava russkikh narodnykh govorov [On the Peculiarities of the Vocabulary of Russian Local Dialects]. In Uchenye zapiski Ural'skogo gosudarstvennogo universiteta. Iss. 2. Yazykoznanie. Sverdlovsk, Izdatel'stvo Ural'skogo universiteta, pp. 58-72.

Kuznetsova, E. V. (1960). O strukture slovarnoi stat'i v oblastnom slovare [On the Structure of a Dictionary Entry in a Regional Dictionary]. In Uchenye zapiski Ural'sk- 
ogo gosudarstvennogo universiteta. Iss. 3. Yazykoznanie. Sverdlovsk, Izdatel'stvo Ural'skogo universiteta, pp. 165-179.

Kuznetsova, E. V. (1963). Vozvratnye glagoly v govorakh Srednego Urala [Reflexive Verbs in the Dialects of the Central Urals]. In Lingvisticheskii sbornik. Iss. 1. Sverdlovsk, Izdatel'stvo Ural'skogo universiteta, pp. 84-95.

Kuznetsova, E. V. (1967). Metod stupenchatoi identifikatsii v opisanii leksiko-semanticheskikh grupp slov [Method of Step-by-step Identification in the Description of Lexical Semantic Groups of Words]. In Mezhvuzovskaya konferentsiya po porozhdayushchim grammatikam. Tezisy dokladov. Tartu, Tartuskii gosudarstvennyi universitet. pp. 65-67.

Kuznetsova, E. V. (1968). Metodicheskie ukazaniya $i$ materialy $k$ spetsseminaru "Sistemnye otnosheniya v leksike" [Methodical Instructions and Materials for the Specialised Seminar "Systemic Relations in Vocabulary"]. Donetsk, S. n. 79 p.

Kuznetsova, E. V. (1978). O sootnoshenii mnogoznachnosti i funktsional'noi ekvivalentnosti slov [On the Correlation between Polysemy and the Functional Equivalence of Words]. In Nauchnye doklady vysshei shkoly. Filologicheskie nauki. No. 2, pp. 97-103.

Kuznetsova, E. V. (1980). Russkaya leksika kak sistema. Uchebnoe posobie [Russian Vocabulary as a System. Textbook.]. Sverdlovsk, Izdatel'stvo Ural'skogo universiteta. 89 p.

Kuznetsova, E. V. (1982). Itogi i perspektivy semanticheskoi klassifikatsii russkikh glagolov [Results and Perspectives of the Semantic Classification of Russian Verbs]. In Kuznetsova, E. V. (Ed.). Semanticheskie klassy russkikh glagolov. Mezhvuzovskii sbornik nauchnykh trudov. Sverdlovsk, Izdatel'stvo Ural'skogo universiteta, pp. 3-10.

Kuznetsova, E. V. (1982). Leksikologiya russkogo yazyka. Uchebnoe posobie [Lexicology of the Russian Language. Textbook]. Moscow, Vysshaya shkola. 216 p.

Kuznetsova, E. V. (1985). Semanticheskaya model' predlozheniya s predikatami tipa "schitat" i sposoby ee realizatsii [The Semantic Model of a Sentence with Predicates of the cyumams Type and Ways to Implement it]. In Adlivankin, S. Yu., Kubryakova, E. S., Cherepanov, I. Yu. (Eds.). Derivatsiya i istoriya yazyka. Tezisy dokladov mezhvuzovskoi nauchnoi konferentsii. Perm', 17-19 June 1985. Perm', Izdatel'stvo Permskogo gosudarstvennogo universiteta.

Kuznetsova, E. V. (1989). Leksikologiya russkogo yazyka. Uchebnoe posobie [Lexicology of the Russian Language. Textbook]. Ed. 2. Moscow, Vysshaya shkola. 216 p.

Kuznetsova, E. V. (Ed.). (1988). Leksiko-semanticheskie gruppy russkikh glagolov. Uchebnyi slovar'-spravochnik [Lexical Semantic Groups of Russian Verbs. Textbook. Dictionary and Reference Book]. Sverdlovsk, Izdatel'stvo Ural'skogo universiteta. 152 p.

Kuznetsova, E. V. (Ed.). (1989). Leksiko-semanticheskie gruppy russkikh glagolov [Lexical-Semantic Groups of Russian Verbs]. Irkutsk, Izdatel'stvo Irkutskogo gosudarstvennogo universiteta. $180 \mathrm{p}$.

Lopushanskaya, S. P. (1997). Slova pamyati ob Ere Vasil'evne Kuznetsovoi. Vspominaniya kolleg ob Ere Vasil'evne Kuznetsovoi [Words of Memory about Era Vasilyevna Kuznetsova. Recollections of Colleagues about Era Vasilyevna Kuznetsova]. In Babenko, L. G. (Ed.). Russkaya glagol'naya leksika: peresekaemost' paradigm. Pamyati Ery Vasil'evny Kuznetsovoi. Yekaterinburg, Izdatel'stvo Ural'skogo universiteta, pp. 488-489.

Ural'skaya semanticheskaya shkola. Ural'skii federal'nyi universitet [The Ural Semantic School. Ural Federal University]. (2013). In Entsiklopediya kognitivnoi lingvistiki: nauchnye shkoly i napravleniya. Tambov, OOO "Tsifra", pp. 14-28.

Vovchok, P. A. (Ed.). (1964-1999). Slovar' russkikh govorov Srednego Urala $v 7 t$. [Dictionary of Russian Dialects of the Central Urals. 7 Vols.]. Sverdlovsk, Sredne-Ural'skoe knizhnoe izdatel'stvo. (Avtor-sostavitel' razdela “Glagol'naya leksika” E. V. Glazyrina).

Zolotova, G. A. (1997). Slova pamyati ob Ere Vasil'evne Kuznetsovoi. Vspominaniya kolleg ob Ere Vasil'evne Kuznetsovoi [Words of Memory about Era Vasilyevna Kuznetsova. Recollections of Colleagues about Era Vasilyevna Kuznetsova]. In Babenko, L. G. (Ed.). Russkaya glagol'naya leksika: peresekaemost' paradigm. Pamyati Ery Vasil'evny Kuznetsovoi. Yekaterinburg, Izdatel'stvo Ural'skogo universiteta, pp. 487-488. 